\title{
The Preventive aspect of Ayurveda in Viral Infection with special reference to COVID-19
}

\author{
Review Article
}

\section{Amit R Nampalliwar ${ }^{1 *}$, Priyanka Bhawsar ${ }^{2}$, Seeta M Biradar ${ }^{3}$}

\author{
1. Reader \& HOD, Department of Roga Nidan \& Vikriti Vigyana, \\ Government Ayurved College \& Hospital, Bilaspur(C.G.)-495001, India. \\ 2. Assistant Professor, Department of Kriya-Sharir, Smt. K.G. Mittal P. Ayurveda College, Mumbai. \\ 3. Associate professor \& HOD, Department of Roganidana, \\ BLDEA'S AVS Ayurveda Mahavidyalaya, Vijayapur, Karnataka, India.
}

\begin{abstract}
In Ayurveda, the management of viral infectious diseases can be either preventive or curative. Prevention is better than cure, while there is no medicine for COVID-19 as of now, it will be good to take preventative measures. In this study for the preventative aspect of Ayurveda in COVID-19, the data has been collected, collated, and reviewed from all available literature related to the topic. It is analyzed that, COVID-19 pandemics can be correlated with janapadadhavnsa roga which are highly communicable diseases described in Ayurveda. It can be correlated as Abhishanga Sannipataj jwara which is of kapha predominance. Ama plays a major role in metabolic disorder patients for invading severe coronavirus disease. Ayurvedic medicines that have Ama pachak and immunity-boosting action play important role in the prevention of COVID-19 infection. Apart from the social distancing and hand washing, local and systemic intervention, Panchakarma therapy and certain use of Rasayana (immunomodulators) have been advocated to prevent the COVID-19.
\end{abstract}

Key Words: Preventive, Ayurveda, Viral Infection, COVID-19, Corona Virus.

\section{Introduction}

The outbreak of the coronavirus came to light in December-2019 when china informed the World health organization (WHO) of a cluster of cases of pneumonia of an unknown cause in Wuhan city. Subsequently, the disease spread in other parts of China and to the rest of the world. Then WHO has declared as it is a pandemic. The virus has been named Severe Acute Respiratory Syndrome CoronaVirus-2 (SARS-CoV-2) and the disease is called as Corona-Virus-Disease-19, in short, it is "COVID-19." (1) The disease has spread globally with more than 18.4 million confirmed cases of COVID-19 in more than 188 countries and territories, resulting in more than 697,000 deaths; more than 11 million people have recovered as of August 5, 2020.(2) In India, the situation of the spread of Corona Virus infection is part of the worldwide pandemic of COVID-19. The pandemic is continuing to spread for this the efforts should be made on clinically-proven prophylaxis and therapeutic strategy. Consequently, the researcher

\section{* Corresponding Author:}

\section{Amit R Nampalliwar}

Reader \& HOD,

Department of Roga Nidan \& Vikriti Vigyana,

Government Ayurved College \& Hospital,

Bilaspur(C.G.)-495001, India.

Email Id: dr.n.amitkumar@gmail.com must draw on other systems of medicine available globally.

In Ayurveda, epidemics are called aupasargik roga and pandemics are janapadadhavnsa roga which are highly communicable diseases that affected mankind since the beginning of human history have been described. In the charak samhita both epidemics and pandemics are clearly described with what preventative measures should be taken. Epidemics are defined as sudden, unexpected outbreaks of disease within a fairly local area and a pandemic is a very widespread of disease that affects the entire nation or the world. Coronavirus infection i.e. COVID-19 is an example of Janapadadhavnsa roga.

As COVID-19 is a viral infection disease spreading all over the world and gets pandemic, we have to prevent this viral infection by various measures that have been described in Ayurveda. As most of the viral infections are self-limiting, leading to either clearance of pathogen or death of the host. A viral infection can lead to a different spectrum of symptoms from asymptomatic to severe disease. Coronaviruses are Coronaviridae family of viruses that cause respiratory disease ranging in severity from the common cold and cough to fatal pneumonia.

Enough strong immunity is required to prevent or cure from COVID-19 pandemic. Ayurveda has a major aim to prevent disease by boosting immunity. Present work may be a brief plan to increase insight during this field. The present review was done based on the basic principles of Ayurveda, 
recent updates regarding prevention of COVID-19, Ayurveda aspect towards viral infection disease, and Ayurveda ways towards prevention of Viral infection with special reference to COVID-19.

Aim:

To study the preventative aspects of Ayurveda in Viral Infection with special reference to COVID-19.

\section{Objective:}

To understand and elaborate on the preventative aspect to protect the Corona Virus infection.

\section{Materials and Methods}

The data has been collected, collated, and reviewed from all available literature related to the subject. Research paper and literature from the internet were also studied critically since COVID-19 is a pandemic problem of the world since few months and there is no solution regarding possible cure treatment.

\section{Observations and Results}

We have analyzed that many research and review papers have been published in the duration of corona cases to the COVID-19 pandemic. In Ayurveda, most of the work was done on preventative aspect only, As Baba Ramdev Ji claims that, Ayurvedic medicine that cures corona infection was developed by his Patanjali pharma company, after advisory of the ministry of health on claims of Baba Ramdev Ji, he was declined curative aspect of Ayurvedic medicine on COVID-19, it is for preventative aspect only as an immunomodulatory effect of the drugs. As prevention is always better than cure, Ayurveda principle can be considered for future strategies to avoid COVID-19 pandemic. There is a need for research work on Preventative as well as Curative aspect of Ayurveda in Viral Infection with special reference to COVID-19.

\section{Concept and understanding of Viral Infection in Ayurveda}

Ayurveda advocates four-fold methods of investigation i.e. Pratyaksha (Direct observation), Anuman (Inference), Aptopdesha (Authoritative testimony), and Yukti (logic) in understanding the visible and invisible things.(3) The signs and symptoms can be known from the patient or directly observed, however, in some conditions, based on the signs and symptoms, the causative factors are inferred because it happens with the viral infection. (4) Many viral infections are either fatal or leave behind complications that can cause permanent disability or affect the quality of life of the patients and have a large scale impact on mortality or morbidity.

According to Ayurveda, a viral infection disease is an epidemics or pandemics that are highly communicable diseases under the term of
Janapadadhwansa where it is mentioned that due to either of deranged of Vayu(air), Jala(water), Desha (habitat) and Kala (seasons).(5) The viral infection disease can be considered as either airborne or waterborne infectious disease or disease occurring due to soil contamination or conditions arising due to change in weather or seasonal hazards. Acharya Sushruta described the 'Aupasargik roga' i.e. contagious disease or spread of disease through contact, for example, the disease like Jwara (fever), Shosha(tuberculosis), Kushta (Skin disease) are contagious and spread through the direct contact or contaminated objects.(6) The causative factor for an infectious disease like fevers, conjunctivitis, common cold or influenza, etc. are also enumerated as due to sexual intercourse, physical contact with diseased individuals, via inhalation of infected respiratory droplets, sharing food, sleeping together, sitting close together, sharing the same clothing, sharing the ornaments, etc. It is also mentioned that in certain conditions like insect bites or poisoning leading to infections requires 21 days of quarantine measure as it is self-limiting.(7) The same thing is happening in the case of coronavirus infection that can spread through direct contact, droplet infection or by contaminated objects and there is a need for isolation to break the chain of infection.

\section{Understanding of COVID-19 through Ayurveda}

Coronaviruses are a large family of viruses that may cause illness in animals \& humans. In humans, most of the corona viruses cause respiratory infection ranging from the common cold to more severe respiratory syndrome such as Middle East Respiratory Syndrome (MERS), Severe Acute Respiratory Syndrome (SARS) and the last year -2019 discovered New Coronavirus causes Novel Corona Virus Disease COVID-19(8)

COVID-19 affects different people in different ways. Most infected people will develop mild to moderate symptoms and recover without hospitalization. The most common symptoms of COVID-19 are fever, dry cough, and tiredness due to respiratory distress. Other symptoms may affect some patients that are usually mild and begins gradually such as aches and pains, sore throat, diarrhea, conjunctivitis, headache, loss of taste or smell, a rash on the skin, or discoloration of peripheral body parts like- fingers or toes. Some people infected by coronavirus only have very mild symptoms.

About $80 \%$ of people recover from the COVID-19 without needing hospital treatment. Old age people and those who have an underlying medical problem like hypertension, diabetes, heart and lung disease, or cancer are at high risk of developing serious illness with Coronavirus infection. However, anyone can infect with COVID-19 and become seriously ill as it depends on the body immune system. Most of the virus infections are self-limiting and there is no need for hospitalization. Same in most of the cases, the 
COVID-19 infections are self-limiting, and very few patients required admission in Hospital.

According to Ayurveda, most of the diseases arise due to mandagni and this mandagni is responsible for the production of $A m a$ (toxins). As Ama accumulates in the body, it inevitably clogs the channels of the body and disrupts tissue nutrition.(9) Ama can disturb physiological processes at the cellular level as well. When Ama finds it's way into the deeper tissues, it coats and clogs individual cell membranes, inhibiting cellular communication and weakening the immune response.(10) Due to weak immune response body cannot fight against the viral infection. In an obese patient, Ama is more accumulated in the body so their immune response becomes weak and they have a more serious illness like COVID-19 than normal people. As WHO mentioned that most obese patients who are suffering from COVID-19 will have a very less immune response against COVID-19, A new study commissioned by researchers in the US confirms that a COVID-19 vaccine may remain ineffective in obese people.(11)

\section{Understating the pathogenesis of COVID-19 through Ayurveda}

The most common symptoms of COVID-19 are Jwara(Fever), Kasa (Cough), and Swasa (respiratory distress), which are belong to Abhatyantara roga marga, described as one of the three roga marga (pathway of disease) in Ayurveda text.(12). Coronavirus mostly enters through the respiratory tract and affects the respiratory system that causes pranavaha stroto dushti.(13) As there is severe respiratory distress along with other symptoms that may be leading to death. COVID-19 can be correlated as Abhishanga Sannipataj jwara which is of kapha predominance as the seat of the affliction of this disease is primarily Urasthana (Chest region) which is the most common site of kapha dosha. As it is sannipataj which aggravates all three doshas. The spread and affliction caused by the coronavirus in this jwara can be understood under the classification of Agantuja jwara. According to Ayurveda, Agantuja jwara caused by an imbalance of three doshas and to be treated as neeja jwara.(14)

\section{Samprapti Ghataka of COVID-19:}

- Dosha: Predominantly -Kapha with both Vata \& Pitta (as anugami dosha)

- Dushya: Rasa dhatu,

- Adhisthan: Sarva Sharir, specially in Urasthana(Chest region)

- Strotansi: Pranavaha, Rasavaha Strotas

- Strotodushti: Sanga, Vimargagaman

- Agni: Mandagni

- Ama: Sama roga

- Vyakta: manifest in the upper body (Respiratory tract) primarily in Kapha region-Urasthana
The preventative aspect of Ayurveda in COVID-19

The main aim of Ayurveda is to prevent the health of a healthy person and cure the disease of an unhealthy person. Ayurveda mainly deals with the preventative $\&$ promotive aspects of the health of the people. The preventative aspect of Ayurveda from the disease by the proper diet and lifestyle regime rather than the treatment of disease.(15) So for the prevention of the disease, we should have to follow diet and lifestyle regimes accordingly.

For prevention of COVID-19 through Ayurveda, the main focus should be to reduce the aggravated and accumulated Kapha and Vata doshas, to purify and unblock the pranavaha and rasavaha strotasa with optimizing the Agni. For this, the interventions include local and systemic intervention, Panchakarma therapy and certain use of Rasayana (immunomodulators) to boost the immune system have been advocated to prevent the COVID-19(16) Local interventions for the preventive measure of Ayurveda in viral infection such as Nasya, KavalaGandusha, Abhyanga, Swedana (steam inhalation) can be practiced as Dincharya (daily regime) that may act as a barrier thereby reducing the risk of viral infection. The local intervention like Nasya and Kavala-Gandusha form the protective layer on nasal and oropharyngeal mucosa respectively which is the most common site of viral infection and may reduce the risk of infection. In Systemic intervention role of Yoga and Pranayama is very important. Yoga is a way to improve the strengths of vital organs and immunity depends on the normal functioning of all these vital organs. Pranayama exercise which related to respiration such as Bhastrika (forceful fast breathing), Anuloma-Viloma (sequential breathing by alternate closing of each nostril), Ujjayi (ocean breath), Sitali (the cooling breath), etc. All these Pranayama are helpful in cleaning the excess mucus accumulated in bronchial alveoli and helps in increasing their immune response.(17) Panchakarma therapy (bio purification) like Vaman, Virechana, Basti, and Nasya can be planned in the persons in the risk of infection areas, to improve the immunity and thus making the risk of infection low.(18) Rasayana deals with the measures for rejuvenation that have properties to enhance growth, induce tissue regeneration, and stimulate immunity. The effect of Rasayana on improving immunity may have direct relevance to the prophylaxis of viral infection. The herbs used in Rasayana have been found to be effective in immunomodulation and restoration of immune haemostatsis.(19) Administration of Rasayana herbs in specific doses form under Ayurvedic physician guidelines can be strong prevention of further spread for COVID-19 among the healthy individuals.

\section{Discussion}

There is no cure for COVID-19 in modern medicine although vaccines are being developed; it will take more time for available in vaccination. So 
as to we need preventative aspects of Ayurveda in Viral infection with special reference to COVID-19. For effective prevention, we have to understand the concept of viral infection through Ayurveda. Charaka Samhita has described dealing with pandemics, as 'Janapadadhwansa' caused by infectious Vayu(air), Jala (water), Desha(Soil or area), and Kala(season). Charaka described the infectious disease and narrates the contamination of physical, chemical, and biological factors in the occurrence of disease.(20)

In Ayurveda the concept of Agni is most important, the strength of Agni in the body is the most critical factor in determining overall health. Mandagni(feeble action of Agni) is the root cause of Ama production. This Ama act as toxins and caused illness due to accumulation in the body, clogs the channels of the body and disrupts tissue nutrition. When Ama finds its way into the deeper tissue, it coats and clogs individual cell membrane, inhibiting cellular communication, and weakening the immune response. (21) People with weak immune responses have a higher risk of bacterial and viral infection, including the virus that causes the infection COVID-19. The AYUSH minister has been advocating the use of traditional Ayurvedic herbs and spices in the form of decoction especially name as "Ayush Kadha" which contain herbs with ushna guna, kaphaghna, and Ama pachak properties to reduce the Ama in body and increase immune response, By the action of this Ayush Kadha on Ama reduction and improving the health, this decoction called as an immune booster which play important role in the prevention of COVID-19 infection. Those who have a metabolic disorder like- obesity, diabetes can take this decoction for preventative purposes.

The most common symptoms of COVID-19 are Jwara(Fever), Kasa(Cough), and Swasa (respiratory distress) belongs to the disease of Abhyantara roga marga as per mentioned in charaka samhita. Coronavirus mostly spread through droplet infection by air and mostly affect the respiratory system that causes pranavaha stroto dushti. In the pathogenesis of COVID-19, the predominantly dosha is Kapha with both Vata \& Pitta affected to a varying degree because the site of the affliction of this disease is upper body region i.e. kapha sthana. Dushya is rasadhatu because the formation of symptoms like- jwara(fever) due to rasavaha stroto dushti. In the sanga type of strotodushti signs and symptoms of COVID-19 may appear 2 to 14 days of incubation period after exposure. The virus replication process begins when a virus infects its host by attaching to the host cell. After replication of the virus, the new viruses burst out of the host cell during a process called lysis and virus spread on another host cell, in this pathogenesis vimargagaman strotodushti occurred.

In Ayurveda, the interventions include local intervention like Nasya and Kavala-Gandusha play an important role in the prevention of viral infection, and in the systemic intervention role of Yoga and Pranayama is very important as this process helps in increasing immune response of vital organs. Panchakarma therapy (bio purification) like Vaman, Virechana, Basti, and Nasya can be planned in the person so as to improve the immunity and thus making the risk of infection low. The effect of Rasayana on improving immunity may have direct relevance to the prophylaxis of viral infection. Administration of Rasayana herbs such as Ashwagandha (Withania somnifera (Linn.) Dunal), Guduchi (Tinospora cordifolia (Willd) Miers ex Hook f. \& Thoms), Shatavari (Asparagus racemosus Willd), Amalki (Emblica officinalis Gaertn.) and Yashtimadhu (Glyceriza glabra Linn.) are potential immunomodulators.(22) The use of Rasayana (immunomodulators) to boost the immune system have been advocated to prevent the COVID-19.

\section{Conclusion}

In Ayurveda, COVID-19 pandemics can be correlated with janapadadhavnsa roga which are highly communicable diseases, due to infectious Vayu(air), Jala(water), Desha(Soil or area) and Kala(season). COVID-19 can be described as 'Aupasargik roga' i.e. infectious disease which is contagious and spread through direct contact or contaminated objects. COVID-19 can be correlated as Abhishanga Sannipataj jwara which is of Kapha predominance as the seat of the affliction of this disease is primarily Urasthana (Chest region) which is the most common site of kapha dosha. Ama plays a major role in metabolic disorder patients like- obese and diabetic patients for invading severe coronavirus disease. Ayurvedic herbs in "Ayush Kadha" which have Ama pachak and immunity-boosting action play important role in the prevention of COVID-19 infection. Local and systemic intervention, Panchakarma therapy and certain use of Rasayana (immunomodulators) to boost the immune system have been advocated to prevent the COVID- 19 .

\section{Acknowledgments}

We thank Dr. Vivek Kumar Dubey for help with developing the illustration.

\section{Funding Support}

No funding was received for this article.

\section{Conflict of Interest}

There is no conflict of interest.

\section{References}

1. https://www.thehindu.com/topic/coronavirus/ latest news, dated: Wednesday 5 August 2020, time 12:24 IST.

2. "COVID-19 Dashboard by the Center for Systems Science and Engineering (CSSE) at Johns Hopkins University (JHU)". ArcGIS. Johns Hopkins University. Retrieved dated: 3 August 2020 time 13.15 IST.

3. Acharya YT, Charaka Samhita of Agnivesha, Sutra Sthana; Titraishaniya adhyaya. Chapter 11, 
Version 26. Varanasi, India: Chaukhambha Orientalia; 2011. p.-87

4. Shubhashree MN, Naik R, Doddamani SH, et al. Preventive strategies to combat infections-a review of traditional practices and Ayurveda concepts. Int J Complement Alt Med. $2020 ; 13(3): 125-129$. DOI: $10.15406 /$ ijcam.2020.13.00505

5. Agnivesha, Charaka Samhita, ayurveda deepika commentary. In: Vaidya Yadavji Trimkamji Acharya publication Choukhamba vishwabharati prakashan Varanasi. India; 2011. P. 241.

6. Acharya NR, Sushruta Samhita Niryansagar Publication, Mumbai 1941. Sutra Sthana 21/37 p.156.

7. Vaghbhata, Astanga Hrudaya, Sarvangasundara vyakhya uttarasthana 6/66 Chaukambha Sanskrit Sansthan. Varanasi; 2011. p.136

8. https://www.who.int/emergencies/diseases/ novel-coronavirus-2019/question-and-answershub/q-a-detail/q-a-coronaviruses dated: 11-10-2020, time 14.24 IST

9. Lad, Vasant. Textbook of Ayurveda, Volume II: A Complete Guide to Clinical Assessment. Albuquerque: The Ayurvedic Press, 2006. Print. 190, 199-202.

10. Lad, Vasant. The Complete Book of Ayurvedic Home Remedies. New York: Three Rivers Press, 1998. Print. 54-55.

11. US Advisory Board: Daily Briefing /August 7, 2020 | Daily Briefing/ Why a coronavirus vaccine could be less effective for obese patients, dated: 12-10-2020, time: 14.28 IST

12. Srikantha Murthy KR. Ashtanga Hrdayam of Vagbhatacharya. translator. Varanasi: Krishnadas Academy; 2003. Reprint. pp.56.

13. $\mathrm{R}$ a $\mathrm{m} \quad \mathrm{K}$ aran $\mathrm{Sh}$ arma, Vaidya Bhagwan Dash (Eds.), Charaka Samhita of Agnivesha, text with the English translation of Ayurveda Dipika commentary of Chakrapanidatta, Vimana sthana 5/7,
Chowkhambha Sanskrit Series, Varanasi (2003) Reprint

14. Sharma RK, Vd. Bhagwan Dash (Eds.), Charaka Samhita of Agnivesha, text with the English translation of Ayurveda Dipika commentary of Chakrapanidatta, Chikitsa sthana 3/128, Chowkhambha Sanskrit Series, Varanasi (2003) Reprint

15. https://nepalayurvedahome.com/preventiveapproach-of-ayurveda/ dated: 13-10-2020, time 16:20 IST.

16. Tillu G., Chaturvedi S., Chopra A., Patwardhan B. Public health approach of Ayurveda and Yoga for COVID-19 prophylaxis. J Alternative Compl Med. 2020;26(5):p.360-364.

17. Kaminsky DA, Guntupalli KK, Lippmann J, et al. Effect of yoga breathing (Pranayama) on exercise tolerance in patients with chronic obstructive pulmonary disease: a randomized, controlled trial. J Altern Complement Med 2017;23:p. 696704.

18. Goyal M. Threats and challenges of emerging viral diseases and scope of Ayurveda in its prevention. AYU 2019;40(3): p.67-8.

19. Agarwal R, Diwanay S, Patki P, et al. Studies on immunomodulatory activity of Withania somnifera (Ashwagandha) extracts in experimental immune inflammation. J Ethnopharmacol 1999;67: p. 27-35

20. Shukla N. Ayurvedic approach to communicable disease -An overview. Open Access Scientific Reports. 2012;1:p. 122.

21. Nampalliwar AR \& Raut SK; Critical Evaluation of Ama Concept And Its Clinical Significance; IAMJ: Volume 6, Issue 9, September - 2018, pp-2170-75.

22. Balasubramani SP, Venkatasubramanian P, Kukkupuni SK, et al. Plant-based Rasayana drugs from Ayurveda. Chin J Integr Med 2011;17: p. $88-94$. 